\title{
The Effects of Different Levels of Nitrogen on Yield and Yield Components of Rainfed Wheat in Two Regions of North Khorasan
}

\author{
Mahdi Bavar, H. Heidari Sharif Abad, Gh. Noormohamadi \\ Department of Agronomy, Science and Research Branch, Islamic Azad University, Tehran, Iran \\ Email: m_bavar22@yahoo.com
}

Received 16 April 2016; accepted 17 June 2016; published 20 June 2016

Copyright (C) 2016 by authors and Scientific Research Publishing Inc.

This work is licensed under the Creative Commons Attribution International License (CC BY). http://creativecommons.org/licenses/by/4.0/

(c) (i) Open Access

\begin{abstract}
To study the effects of different levels of nitrogen fertilizer on yield and yield components of cultivars of rainfed wheat a study was done in the crop year 2012-2013 as factorial in a randomized complete block design with 3 replications, in 2 research stations of Kohne Kand city in Bojnord and Shirvan dryland research station. The treatments of study contain cultivars of wheat in 4 levels (Rasad, Sabalan, Cross Sabalan and Azar 2) and 4 levels of nitrogen fertilizer (75, 50, 25 and 0 kilograms nitrogen per hectare). The results showed that the yield in Shirvan was significantly higher than that in Bojnoord. Moreover, the impact of cultivar and nitrogen on yield and yield components was significant in both regions and among different cultivars Azar 2 has the highest yield in both regions and the lowest yield was for cross Sabalsn in Shirvan and Sabalan in Bojnoord. Furthermore, yield increased by increasing the nitrogen in both regions but there was no significant difference between levels 50 and 75 kilograms per hectare. Among yield components except the number of spikes per square meter, others had a high correlation with yield.
\end{abstract}

\section{Keywords}

Wheat, Nitrogen, Yield, Yield Components, Cultivars of Rainfed

\section{Introduction}

Wheat is one of the three cereals which has the most cultivated land in the world and dedicated to itself about one-third of the world's arable land (Emam, 2007) [1]. This plant has an important role in feeding people around the world (Ying Li et al., 2016) [2]. According to the statistics of Food and Agriculture Organization (FAO) in 2010 the cultivated land of wheat equals 217 million hectares, with production amounted to 653 million tons and 
about $44 \%$ of its production is in Asian countries and due to the large share of production, Asia is the world's largest producer of wheat. In Iran according to available statistics 6.4 million hectares of country lands devoted to wheat that $62.5 \%$ of them were used for dryland farming. Despite vast cultivated land, less than $31 \%$ of wheat production comes from rainfed farms (Ministry of Agriculture Statistics 2013) [3], and this reveals the importance of attention to rainfed wheat. In semi-arid areas production depends mainly on rain. The most important factors limiting growth and yield of plants in these areas are limitation of water resources and minimal access to nutrients (Zhao-Hui, 2008; Lee et al., 2001) [4] [5].

In dryland farming food must be provided based on soil moisture regimes. Since it is impossible to accurately predict rainfall and changes in time and amount of rainfall is high, so the exact determination of the required fertilizer for wheat in dryland conditions, especially nitrogen fertilizer is one of the most difficult and risky decisions that farmers in these areas should take (Arnon, 1972) [6].

Nitrogen is one of the most important macronutrients that are used highly in today's input agriculture (Latirisouki et al., 1998 [7]; Lawlor, 1995 [8]). Nitrogen at the cellular level increases the number and size of cells and increases the leaf area and the efficiency of radiation absorption by plant (Jenkyn and Luch, 1998 [9]; Marbet, 2000 [10]). Rise of nitrogen also increases the durability of the leaf area and biomass (Basso \& Ritchie, 2005 [11]; Yang et al., 2001 [12]). Wheat production in arid and semi-arid areas largely depends on nitrogen management. In these areas, due to the low soil organic matter, nitrogen is the most important limiting element of yield. Nitrogen mineralization in these areas is not sufficient for the needs of cereals and the use of appropriate amounts of nitrogen fertilizer to increase yield in these areas is essential (Ryan, 2002 [13]; Ryan et al., 2008 [14]).

Suitable nitrogen application in dryland conditions can increase the power of plant to deal with the drought in these conditions (Fischer, 1973 [15]; Langdate et al., 1973 [16]). Results of several studies have shown that nitrogen fertilizer increases grain yield and its protein. Asadi et al., (2013) [50] investigated the effects of different levels of nitrogen and competition on grain yield and reported that with increase of nitrogen grain yield increased.

Dandan Liu \& Yan Shi, (2013) [17] investigated different amounts of nitrogen fertilizer on yield and grain quality and reported that grain quality and yield increased with the increase of nitrogen fertilizer. Emam et al., (2011) [18] also reported the increase of yield and yield components in rainfed wheat by increase of nitrogen fertilizer.

On the other hand excessive use of nitrogen fertilizer in rainfed wheat leads to an increase in the growth period, production of more vegetative organs and ultimately decreases of grain yield, increase of the number of infertile grains and decrease of harvest index (Basso \& Ritchie, 2005 [11]; Fischer, 1973 [15]). So determining the appropriate level of nitrogen in dry lands which causes the maximum yield has particular importance in dryland areas.

\section{Methods and Materials}

To study the effects of different levels of nitrogen fertilizer on yield and yield components of cultivars rainfed wheat a study was done in the crop year 2012-2013 as factorial in a randomized complete block design in 2 research stations of Kohne Kand city in Bojnord (latitude 37 degrees 28 minutes north and longitude 57 degrees 20 minutes east, and altitude of 1070 meters) and Shirvan (latitude 37 degrees 19 minutes north and longitude 58 degrees 07 minutes east, and altitude of 1148 meters) research station with 3 replications. The treatments of study contain nitrogen fertilizer in 4 levels (75, 50, 25 and 0 kilograms nitrogen per hectare) and 4 cultivars of rainfed wheat (Sabalan, Cross Sabalan, Azar 2 and Rasad). To prepare the land for planting first plowing was done by chisel plow and then the disc was used to grind clods, and then by the use of leveler land was leveled. After that land was divided to plots with a length of 5 and a width of 2 meters. In per plot 8 plant lines with a spacing of $20 \mathrm{~cm}$ are considered and lines next to each plot were considered as marginal effect. Planting was done on October 23 with a density of 300 plants in per square meter (common planting date and density in region) with the spraying method. Consumable fertilizers were used based on fertilizer recommendations, including nitrogen in stages (sowing, tillering and stem elongation and along with rain) and phosphorus as 50 kilograms per hectare that was used at the same time with planting. Tribenuron was used to fight with weeds.

To measure yield from the two middle rows that remain intact and of each row 0.5 meter was harvested and transported to the laboratory. Yield components were measured after harvest. 10 plants were chosen and number 
of spikes per square meter, number of grains per spike and weight of one thousand grains was measured. Finally data were analyzed using SAS software. Comparison of the average data was conducted at the level of $5 \%$ and with Duncan test.

\section{Results and Discussions}

\subsection{Yield}

The results showed that the effects of different cultivars and different amounts of nitrogen fertilizer on yield and yield components were significant in both regions (Table 1). In both regions Azar 2 had the highest yield and lowest yield was related to the Cross Sabalan in Shirvan and Sabalan in Bojnoord. With the increase of nitrogen fertilizer, yield was significantly increased too. However, there was no significant difference between levels 50 and 75 kilograms nitrogen per hectare (Table 3).

Moraghebi et al., (2011) [19] also reported that along with nitrogen increase, grain yield, grain protein and grain protein yield increased linearly. Increase of grain yield by increase of nitrogen obeys the law of diminishing returns; that means yield increases with increase of nitrogen consumption but yield increase at higher amounts of nitrogen gradually becomes less. This would correspond with the findings of other researchers (Alcozen et al., 1993 [20]; Sowers et al., 1994 [21]).

\subsection{Yield Components}

\subsubsection{Number of Spikes per Square Meter}

The effects of cultivar and different amounts of nitrogen fertilizer were significant on the number of spikes per square meter (Table 1) and Cross Sabalan has the highest number of spikes per square meter (Table 2) but it has the least yield and it shows the low role of this factor in increase of yield in rainfed conditions. Many evidences indicate that yield components of grain are more or less dependent to each other. For example, more spikesper unit area are neutral with fewer grains per spike (Evanze, 1984) [22]. With the increase of nitrogen in used treatments, the number of fertile tillers per plant increased too (Hosseini et al., 2011) [23] but the reaction of dissimilar genotypes was different (Giovanni et al., 2004) [24].

\subsubsection{Number of Grains per Spike}

The impact of cultivar on the number of grains per spike was significant (Table 1) and Azar 2 had the most number of grains per spike. High yield in Azar 2 is because of the number of grains per spike and higher weight of thousand grains in this cultivar in comparison to others (Table 2). In dryland conditions the number of grains per spike is more important than other characteristics. This may be due to the importance of this attribute and its

Table 1. Analysis of variance of experimental characteristics.

\begin{tabular}{|c|c|c|c|c|c|c|c|}
\hline \multicolumn{8}{|c|}{ Mean square } \\
\hline S.O.V & Fd & $\begin{array}{c}\text { Number of } \\
\text { spikelet per } \mathrm{m}^{2}\end{array}$ & $\begin{array}{c}\text { Number of } \\
\text { seed in } \\
\text { spikelet }\end{array}$ & $\begin{array}{l}1000 \text { Grain } \\
\text { weight }\end{array}$ & Yield & Biomas & $\begin{array}{l}\text { Harvest } \\
\text { index }\end{array}$ \\
\hline Place & 1 & $0.844^{\mathrm{ns}}$ & $128.344^{* *}$ & $51.042^{* *}$ & $5.818^{* *}$ & $32.034^{* *}$ & $15.360^{*}$ \\
\hline Repeat & 4 & $37.8021^{\mathrm{ns}}$ & $31.469^{* *}$ & $0.990^{\mathrm{ns}}$ & $0.233^{* *}$ & $0.160^{*}$ & $27.473^{* *}$ \\
\hline Cultivar & 3 & $56756.705^{* *}$ & $620.316^{* *}$ & $253.514^{* *}$ & $2.796^{* *}$ & $6.247^{* *}$ & $215.333^{* *}$ \\
\hline Nitrogen & 3 & $7498.455^{* *}$ & $590.260^{* *}$ & $16.014^{* *}$ & $2.795^{* *}$ & $5.091^{* *}$ & $341.285^{* *}$ \\
\hline $\mathrm{C} \times \mathrm{N}$ & 9 & $2212.622^{* *}$ & $9.575^{* *}$ & $5.486^{* *}$ & $0.021^{*}$ & $0.0408^{\mathrm{ns}}$ & $5.026^{\mathrm{ns}}$ \\
\hline $\mathrm{P} \times \mathrm{C}$ & 3 & $739.510^{*}$ & $0.622^{\mathrm{ns}}$ & $1.014^{\mathrm{ns}}$ & $0.311^{* *}$ & $1.211^{* *}$ & $121.106^{* *}$ \\
\hline $\mathrm{P} \times \mathrm{N}$ & 3 & $269.538^{\mathrm{ns}}$ & $0.066^{\mathrm{ns}}$ & $0.181^{\mathrm{ns}}$ & $0.003^{\text {ns }}$ & $0.121^{\mathrm{ns}}$ & $13.193^{* *}$ \\
\hline $\mathrm{P} \times \mathrm{C} \times \mathrm{N}$ & 9 & $256.946^{\mathrm{ns}}$ & $0.344^{\mathrm{ns}}$ & $0.338^{\mathrm{ns}}$ & $0.007^{\mathrm{ns}}$ & $0.081^{\mathrm{ns}}$ & $7.049^{*}$ \\
\hline C.V.\% & & 4.965 & 3.826 & 4.199 & 5.011 & 4.399 & 4.221 \\
\hline
\end{tabular}

ns $,{ }^{* *},{ }^{*}:$ non-significant and significant, respectively, at the level of 1 per cent and five percent. 
sensitivity to drought conditions and its applied pattern (Collaku, 1989) [25]. Shahbaz Panahi et al., (2012) [26] reported that the number of grains per spike in drought conditions significantly affects grain yield and with the increase of nitrogen, number of spikes per square meter and number of grains per spike increased (Table 2, Table 3). This can be attributed to the role of nitrogen in increasing growth and grain yield (Shahzad et al., 2013) [27]. Determining the most important characteristics and wheat yield components and their correlation with grain yield causes suitable genotypes be selected and used to increase the yield per unit area (Nabipour et al., 2002) [28].

Hanchinal et al., (1994 [29]) suggested number of grains per wheat spike as the most critical attribute for the selection of drought resistant genotypes. According to Ehdaie \& Noor Mohammadi (1994) [30] correlation between grain yield and its components, plant height, number of spikes per plant and number of grains per spike is positive and significant in unfavorable environmental conditions.

\subsubsection{The Weight of One Thousand Grains}

The effect of nitrogen and cultivar was significant on the weight of one thousand grains (Table 1). High yield of Azar 2 in comparison to other cultivars is because of the number of grains per spike and the high weight of one thousand grains in this cultivar in comparison to others (Table 2). So high weight of one thousand grains as one of the most important components of grain yield in drought conditions should be considered as a criterion for the selection of drought tolerant genotypes (Sanjari \& Yazdansepas, 2009 [31]; Rezadoost \& Roshdi, 2006 [32]; Yazdansepas et al., 2010 [33]).

Alavisiny et al., (2013) [34] also reviews the resistance of different wheat lines to drought conditions and stated that the role of weight of one thousand grains in yield in comparison to other yield components is more. With the increase of nitrogen, weight of one thousand grains reduced and had inverse relation with other yield components (Table 3). Usually correlation between wheat grain yield with weight of one thousand grains, plant height, number of tillers per square meter, length of the last peduncle, number of grains per spike, biological yield and harvest index is positive and significant (Mohammadi, 1998) [51].

High yield in Shirvan in comparison to Bojnoord can be attributed to the difference in rainfall and soil properties in these areas that is discussed below.

Table 2. Mean comparison of yield and yield components for different cultivars.

\begin{tabular}{|c|c|c|c|c|c|c|c|c|}
\hline \multirow{2}{*}{$\begin{array}{c}\text { Cultivar } \\
\text { Place }\end{array}$} & \multicolumn{2}{|c|}{ Number of spikelet per $\mathrm{m}^{2}$} & \multicolumn{2}{|c|}{ Number of seed per spikelet } & \multicolumn{2}{|c|}{$\begin{array}{l}\text { Thousand } \\
\text { grain weight (gr) }\end{array}$} & \multicolumn{2}{|c|}{ Yield (ton/ha) } \\
\hline & Shi & Boj & Shi & Boj & Shi & Boj & Shi & Boj \\
\hline Rasad & 259.833c & 254.917d & $29.000 \mathrm{~b}$ & $26.583 b$ & 34.500a & 32.583a & 2.398a & $1.928 b$ \\
\hline Sabalan & $315.417 b$ & 309.750b & 24.917c & $22.417 \mathrm{c}$ & $28.917 \mathrm{~b}$ & $28.000 \mathrm{~b}$ & $2.041 \mathrm{~b}$ & $1.253 \mathrm{~d}$ \\
\hline Azar 2 & $273.083 c$ & $267.583 c$ & 32.833a & 30.333a & 33.583a & 32.083a & $2.589 \mathrm{c}$ & $2.109 a$ \\
\hline Crossabalan & $356.750 a$ & 373.583a & 20.750d & 18.917d & $27.667 \mathrm{c}$ & $26.167 \mathrm{c}$ & $1.833 \mathrm{~d}$ & $1.600 \mathrm{c}$ \\
\hline
\end{tabular}

Means with similar letters in each column are not significantly different at the 5\% level of probability (Donckan).

Table 3. Mean comparison of yield and yield components for different levels of nitrogen.

\begin{tabular}{ccccccccccc}
\hline & \multicolumn{9}{c}{ Mean } \\
\cline { 2 - 9 } & \multicolumn{1}{c}{ Numbr of spikelet per $\mathrm{m}^{2}$} & Number of seed per spikelet & 1000 Grain weight (gr) & Yield (Ton/ha) \\
\hline Amount N (Kg/ha) & Shi & Boj & Shi & Boj & Shi & Boj & Shi & Boj \\
0 & $290.083 \mathrm{~b}$ & $281.167 \mathrm{~b}$ & $20.833 \mathrm{~d}$ & $18.667 \mathrm{~d}$ & $32.333 \mathrm{a}$ & $30.833 \mathrm{a}$ & $1.717 \mathrm{c}$ & $1.253 \mathrm{c}$ \\
25 & $283.667 \mathrm{~b}$ & $289.417 \mathrm{~b}$ & $25.250 \mathrm{c}$ & $22.917 \mathrm{c}$ & $31.250 \mathrm{~b}$ & $29.583 \mathrm{~b}$ & $2.223 \mathrm{~b}$ & $1.722 \mathrm{~b}$ \\
50 & $315.500 \mathrm{a}$ & $320.167 \mathrm{a}$ & $28.917 \mathrm{~b}$ & $26.500 \mathrm{~b}$ & $30.417 \mathrm{~b}$ & $29.000 \mathrm{~b}$ & $2.440 \mathrm{a}$ & $1.956 \mathrm{a}$ \\
75 & $315.833 \mathrm{a}$ & $315.083 \mathrm{a}$ & $32.500 \mathrm{a}$ & $30.167 \mathrm{a}$ & $30.667 \mathrm{~b}$ & $29.417 \mathrm{~b}$ & $2.480 \mathrm{a}$ & $1.960 \mathrm{a}$ \\
\hline
\end{tabular}

Means with similar letters in each column are not significantly different at the $5 \%$ level of probability (Donckan). 


\subsubsection{Effects of Rainfall on Yield}

Despite the high resistance of wheat to drought, rainfall and adequate water supply has a major impact on grain yield so that high yield in Shirvan in comparison to Bojnoord can be related to higher rainfall in Shirvan (Table 4). Nasabian et al., (2004) [35] in examining the effects of temperature and rainfall on strategic products stated that per millimeter increase in rainfall and rising temperatures, greatly increase the yield.

Azizi \& Yar Ahmadi (2003) [36] by the use of regression model studied the relationship between climatic factors and yield of rainfed wheat in plain Syalkhor in Lorestan. Using parameters of autumn and spring rainfall rate, number of spring frost days, first autumn rainfall and number of rainy days, they showed that there is a direct relationship between the yield of rainfed wheat and variables of autumn rainfall and also number of rainy days during the humid period of the year; and there is an inverse relationship between the number of frost days in spring and the delay in the first rainfall of autumn. Norwood (2000) [37] examined the effect of climatic factors on the rainfed wheat growing areas in the Great Plains of Kansas in America. He identified suitable areas for growing rainfed wheat by the analysis of climatic data such as rainfall, temperature, evaporation and soil and concluded that evaporation and rainfall compared to other climatic elements have the greatest impact during the growth stages of rainfed wheat.

Verdin \& Klaver (2002) [38] and Moeletsi \& Walker (2012) [39] showed that rainfall and water use and evapotranspiration have significant effects on rainfed crops yield.

In addition to the amount of rainfall, time of rainfall is very important too. Higher rainfall in November in Bojnoord than in Shirvan (Table 4) caused that growing happens sooner in this region (Table 5). At stem elongation stage Bojnoord rainfall was higher than Shirvan butat the time of grain filling that coincides with May (Table 5) rainfall in Shirvan was doubled (Table 4). This indicates that in dryland conditions, rainfall and wheat access to water at the time of grain filling has the greatest impact on yield and is very important. Studies that have been carried out in Tunisia show that the relationship between rainfall, time of grain filling and the atmosphere performance is positive and significant so that for each millimeter rise in precipitation over the annual rainfall average $(450 \mathrm{~mm}$ ) will be added to the product 6 kilograms per hectare (Watts \& El-Mourid, 1988) [40].

Table 4. Mean, max and min temperature, amount of rainfall from planting to harvesting.

\begin{tabular}{|c|c|c|c|c|c|}
\hline Place & Month & Min tem & Max temp & Mean temp & Rain (mm) \\
\hline Shi & Nov & 0.7 & 7 & 10.3 & 24.2 \\
\hline Boj & & -1.2 & 24.2 & 11.5 & 39.7 \\
\hline Shi & Dec & -4.7 & 12.8 & 4.1 & 21.8 \\
\hline Boj & & -3.2 & 15.8 & 6.3 & 17.4 \\
\hline Shi & Jan & -16.5 & 9.7 & -2.4 & 41.4 \\
\hline Boj & & -15 & 15.2 & 0.75 & 12.3 \\
\hline Shi & Feb & -4.1 & 13.3 & 5.4 & 16.8 \\
\hline Boj & & -3.8 & 18 & 12.3 & 20.6 \\
\hline Shi & Mar & -3.6 & 20.3 & 5.9 & 66.6 \\
\hline Boj & & -5 & 25.2 & 6.2 & 24.2 \\
\hline Shi & Apr & 1.3 & 22.3 & 11.1 & 13.6 \\
\hline Boj & & -2 & 27.2 & 11.9 & 20.2 \\
\hline Shi & May & 1.7 & 10.8 & 14.2 & 55.5 \\
\hline Boj & & 1.4 & 30.2 & 15.2 & 23.2 \\
\hline Shi & Jun & 8.2 & 37.2 & 22.2 & 22.2 \\
\hline Boj & & 9 & 36.4 & 22.1 & 16.3 \\
\hline \multirow[t]{2}{*}{ Sum of rain } & Shi & & & & 262.1 \\
\hline & Boj & & & & 173.9 \\
\hline
\end{tabular}


Table 5. Phenology stages.

\begin{tabular}{|c|c|c|c|c|}
\hline \multirow[t]{2}{*}{ Phenology stage } & \multicolumn{2}{|c|}{ Date } & \multicolumn{2}{|c|}{ GDD } \\
\hline & Shi & Boj & Shi & Boj \\
\hline Emergence & Dec & Nov & 320.5 & 196.8 \\
\hline Tillering & Mar & Feb & 515.2 & 580.5 \\
\hline Stem extension & Apr & Mar & 932.5 & 882 \\
\hline Anthesis & May & May & 1388.8 & 1485.1 \\
\hline Maturity & Jun & Jun & 2071.5 & 2277.8 \\
\hline
\end{tabular}

Table 6. Soil analysis of experimental farm at $0-30 \mathrm{~cm}$.

\begin{tabular}{ccc}
\hline & Shirvan & Bojnourd \\
\hline $\mathrm{pH}$ & $7 / 9$ & 7.85 \\
EC & 0.51 & 2.02 \\
Percent of organic matter & 0.49 & 0.2 \\
Percent of N & 0.096 & 0.01 \\
Percent of P & ppm 8.8 & ppm 13.45 \\
Percent of K & ppm227 2760 \\
Soil texture & Loam silty & Loam silty \\
\hline
\end{tabular}

\subsubsection{The Effects of Soil Organic Matter on Yield}

Another factor influencing the increase of yield in Shirvan in comparison to Bojnoord is more soil organic matter (Table 6). Soil organic matter plays an important role in soil quality. Humus is a part of that and is essential for controlling $\mathrm{pH}$, water and minerals holding capacity, increase of soil aggregate stability and reduction of water and wind erosion (Tisdal \& Oades, 1982 [41]; Lal, 2003 [42]; Albercht \& Rasmusen, 1998 [43]).

Kazemaini et al., (2008) [52] studied effects of nitrogen and soil organic matter on rainfed wheat yield in Shiraz and stated that with the increase of nitrogen and soil organic matter, wheat yield increased significantly.

\subsubsection{Soil Salinity}

Moreover, soil salinity in Bojnoord was higher than in Shirvan (Table 6). The sensitivity of the final yield to salinity, as well as other environmental stresses, is a function of the sensitivity of each of the different components of the yield to stress (Pesarrakli, 1999) [44]. As grain yield, total dry weight reduces in saline environment (Mostajeran et al., 2005 [45]). Maas \& Grieve (1990) [46] stated that salinity changed spike final capacity which caused a significant decrease in spike length, number of spikes per unit area and also number of grains per spike.

Francois et al., (1994) [47] studied the effect of salinity on wheat growth and yield components in three different phonological periods (use of salinity in the growing season, before the differentiation of terminal spikelet and after the differentiation of terminal spikelet) and declared that use of salinity before the differentiation of terminal spikelet reduced the number of spikelets per spike and the number of tillers whereas the use of salinity after the differentiation of terminal spikelet only significantly reduced the number of grains and grain weight. Francois et al., (1986) [48] announced that salinity decreased grain yield by reducing the weight of the grain. Maas \& Poss (1989) [49] expressed that soil salinity affected wheat yield before heading stage more than after that.

\section{References}

[1] Emam, Y., Ranjbaran, A.M. and Baharani, M.J. (2007) Evaluation of Yield and Yield Components in Wheat Genotypes under Post-Anthesis Drought Stress. JWSS-Isfahan University of Technology, 11, 317-328.

[2] Li, Y., Yu, J.M., Goktepe, I. and Ahmedna, M. (2016) The Potential of Papain and Alcalase Enzymes and Process Op- 
timizations to Reduce Allergenic Gliadins in Wheat Flour. Food Chemistry, 196, 1338-1345. http://dx.doi.org/10.1016/j.foodchem.2015.10.089

[3] Agricultural Statistics. The First Volume of the Crops “Crop Year 2012-2013”. Bureau of Statistics and Information and Communications Technology in Ministry of Agriculture, $121 \mathrm{p}$.

[4] Liu, Z.-H., Jiang, L.-H., Li, X.-L., Hardter, R., Zhang, W.-J., Zhang, Y.-L. and Zheng, D.-F. (2008) Effect of N and K Fertilizers on Yield and Quality of Greenhouse Vegetable Crops. Pedosphere, 18, 496-502. http://dx.doi.org/10.1016/S1002-0160(08)60040-5

[5] Lee, T., Oh, D.W., Kim, H.S., Lee, J., Kim, Y.H., Yun, S.H. and Lee, Y.W. (2001) Identification of Deoxynivalenoland Nivalenol-Producing Chemotypes of Gibberella Zeae by Using PCR. Applied and Environmental Microbiology, 67, 2966-2972. http://dx.doi.org/10.1128/AEM.67.7.2966-2972.2001

[6] Arnon, I. (1972) Principals of Agriculture in Arid Regions. Vol. 1 and 2, Astan Quds Razavi Publisher.

[7] Latiri-Souki, K., Nortcliff, S. and Lawlor, D.W. (1998) Nitrogen Fertilizer Can Increase Dry Matter, Grain Production and Radiation and Water Use Efficiencies for Durum Wheat under Semi-Arid Conditions. European Journal of Agronomy, 9, 21-34. http://dx.doi.org/10.1016/S1161-0301(98)00022-7

[8] Lawlor, D.W. (1995) The Effects of Water Deficit on Photosynthesis in Environment and Plant Metabolism. In: Smirnoff, N., Ed., Bioss Scientific Publishers, Oxford, 129-160.

[9] Jenkyn, S.H. and Luch, T.M. (1998) The Kinetic of Straw Decomposition in Relation to Its Potential to Produce the Phytotoxin. Journal of Soil Science, 32, 627-632.

[10] Marbet, R. (2000) Differential Response of Wheat to Tillage Management Systems in a Semi-Arid Area of Morocco. Field Crops Research, 66, 165-174. http://dx.doi.org/10.1016/S0378-4290(00)00074-5

[11] Basso, B. and Ritchie, J.T. (2005) Impact of Compost, Manure, and Inorganic Fertilizer on Nitrate Leaching and Yield for a 6-Year Maize-Alfalfa Rotation in Michigan. Agriculture, Ecosystems \& Environment, 108, 329-341. http://dx.doi.org/10.1016/j.agee.2005.01.011

[12] Yang, J., Zahang, J., Huang, Z., Zhu, Q. and Wang, W. (2001) Remoblization of Carbon Reserves in Response to Water Deficit during Grain Filling of Rice. Field Crops Research, 71, 47-55. http://dx.doi.org/10.1016/S0378-4290(01)00147-2

[13] Ryan, J. (2002) Available Soil Nutrients and Fertilizer Use in Relation to Crop Production in the Mediterranean Area. In: Krishna, K.R., Ed., Soil Fertility and Crop Production, Science Publisher, Inc., Enfield, 213-246.

[14] Ryan, J., Pala, M., Masri, S., Singh, M. and Harris, H. (2008) Rainfed Wheat-Based Rotations under Mediterranean Conditions: Crop Sequences, Nitrogen Fertilization, and Stubble Grazing in Relation to Grain and Straw Quality. European Journal of Agronomy, 28, 112-118. http://dx.doi.org/10.1016/j.eja.2007.05.008

[15] Fischer, R.A. (1973) The Effect of Water Stress at Various Stages of Development on Yield Process in Wheat. Australian Journal of Agricultural Research, 29, 897-912. http://dx.doi.org/10.1071/AR9780897

[16] Langdale, G.W., Perkins, H.F., Barnett, A.P., Reardon, J.C. and Wilson Jr., R.L. (1973) Soil and Nutrient Runoff Losses with In-Row, Chisel-Planted Soybeans. Journal of Soil and Water Conservation, 38, 297-301.

[17] Liu, D.D. and Shi, Y. (2013) Effects of Different Nitrogen Fertilizer on Quality and Yield in Winter Wheat. Advance Journal of Food Science and Technology, 5, 646-649.

[18] Emam, Y. (2011) Cereal Production. 4th Edition, Shiraz University Press, Shiraz, 190 p.

[19] Moraghebi, F., Akbarifamyle, M. and Hooshmandfar, A. (2011) Effects of Rate and Time of Nitrogen Fertilizer on Percent of Seed Protein and Nitrogen Utilization Efficiency at Pishtaz Cultivar of Wheat in Saveh Region. Plant and Ecology Journal, 7, 65-76.

[20] Alcoz, M.M., Hons, F.M. and Haby, V.A. (1992) Nitrogen Fertilization Timing Effect on Wheat Production, Nitrogen Uptake Efficiency, and Residual Soil Nitrogen. Agronomy Journal, 85, 1198-1203. http://dx.doi.org/10.2134/agronj1993.00021962008500060020x

[21] Sowers, K.E., Pan, W.L., Miller, B.C. and Smith, J.L. (1993) Nitrogen Use Efficiency of Split Nitrogen Applications in Soft White Winter Wheat. Agronomy Journal, 86, 942-948. http://dx.doi.org/10.2134/agronj1994.00021962008600060004x

[22] Evans, E.G. (1984) Pre-Anthesis Growth and Its Influence on Seed Yield in Winter Oilseed Rape. Aspects of Applied Biology, 6, 81-90.

[23] Hosseini, R., Galeshi, S., Soltani, A. and Kalateh, M. (2011) The Effect of Nitrogen on Yield and Yield Component in Modern and Old Wheat Cultivars. Electronic Journal of Crop Production, 4, 187-199.

[24] Guarda, G., Padovan, S. and Delogu, G. (2004) Grain Yield, Nitrogen-Use Efficiency and Baking Quality of Old and Modern Italian Bread-Wheat Cultivars Grown at Different Nitrogen Levels. European Journal of Agronomy, 21, 181192. 
[25] Collaku, A. (1989) Analysis of the Structure of Correlations between Yield and Some Quantitative Traits in Bread Wheat. Buletini i Shkencave Bujqesore, 28, 137-144.

[26] Shahbazpanahi, B., Paknejad, F., Habibi, D., Sadeghi Shoaa, M., Nasri, M. and Pazoki, A. (2012) Evaluation of Irrigation Regimes on Yield and Yield Componente in Different Cultivars of Wheat (Triticum aestivum L.). Iranian Journal of Agronomy and Plant Breeding, 8, 185-197.

[27] Shahzad, K.H., Khan, A. and Nawaz, I. (2016) Response of Wheat Varieties to Different Nitrogen Levels under Agro-Climatic Conditions of Mansehra. Science Technology and Development, 32, 99-103.

[28] Nabipour, A.R., Yazdi Samadi, B., Zali, A.A. and Poustini, K. (2002) Effects of Morphological Traits and Their Relations to Stress Susceptibility Index in Several Wheat Genotypes. BIABAN, 7, 31-47.

[29] Hanchinal, R.R., Tandon, J.P. and Salimath, P.M. (1994) Variation and Adaptation of Wheat Varieties for Heat Tolerance in Peninsular India. Proceedings of the International Conferences, Wad Medani, 1-4 February 1993 and Dinajpur, 13-15 February 1993, 175-183.

[30] Ehdaei, B., Noormohammadi, G.H. and Vala, A. (1994) Environmental Susceptibility and Grain Yield Correlation with Its Components in Khozestan Tetraploied Wheat (Durum). Journal of Scientific Agricultural, 17, 15-31.

[31] Sanjari Pireivatlou A and Yazdansepas, A. (2008) Genotypic Variation of the Trait Stem Reserves in Bread Wheat (Triticum aestivum L.) Genotypes under Post Anthesis Drought Stress Condition. Iranian Journal of Field Crop Science, 39, 181-191.

[32] Rezadost, S. and Roshdi, M. (2006) New Cultivar Wheat Reactions towards Insufficient Irrigation Systems. Journal of Agricultural Sciences, 12, 123-131.

[33] Yazdansepas, A., Rezaie, M., Chiychi, M., Nazeri, M., Razave, S.A., Sanjare, A.G., Abede, M.S., Babaei, T., Soltane, R., Salehe, P. and Hosenebay, S.K. (2010) Study of the Morpho-Physiological Traits and Stability of Grain Yield in Promising Winter and Facultative Wheat (Triticum aestivum L.) Genotypes in Cold Regions. Seed and Plant Improvement Institute, Final Report No. 40143.

[34] Alavi Sini, S.M., Saba, J. and Nasiri, J. (2013) Evaluation of some Physiological Traits in Drought Tolerant Lines of Bread Wheat in Rainfed Conditions. Seed and Plant Improvement Journal, 29, 637-657.

[35] Nasabian, S.H. and Sadroleshraghi, S.M. (2004) Study Effect Rain and Temperature on Yield of Farm Crops. Agriculture Science Journal, 10, 35-50.

[36] Azizi, Gh. and Yarahmadi, V.D. (2003) The Relationship between Climatic Factors and Wheat Yield Using the Regression Model (Syalkhor Plain Case Study). Journal of Geography, No. 44, 52-58.

[37] Norwood, C.A. (1999) Dryland Winter Wheat as Affected by Previous Crops. Agronomy Journal, 92, 121-127. http://dx.doi.org/10.2134/agronj2000.921121x

[38] Verdin, J. and Klaver, R. (2002) Grid-Cell-Based Crop Water Accounting for the Famine Early Warning System. Hydrological Processes, 16, 1617-1630. http://dx.doi.org/10.1002/hyp.1025

[39] Moeletsi, M.E. and Walker, S. (2012) Evaluation of NASA Satellite and Modelled Temperature Data for Simulating Maize Water Requirement Satisfaction Index in the Free State Province of South Africa. Physics and Chemistry of the Earth, Parts A/B/C, 50-52, 157-164. http://dx.doi.org/10.1016/j.pce.2012.08.012

[40] Watts, D.G and El Mourid, M. (1988) Rainfall Patterns and Probabilities in the Semiarid Cereal Production Region of Morocco. Special Publication, Aridoculture Center, Settat, Morocco, USAID Project No. 608-0136.

[41] Tisdall, J.M. and Oades, J.M. (1982) Organic Matter and Water-Stable Aggregates in Soils. Journal of Soil Science, 33, 141-163. http://dx.doi.org/10.1111/j.1365-2389.1982.tb01755.x

[42] Lal, R. (2003) Soil Erosion and the Global Carbon Budget. Environment International, 29, 437-450. http://dx.doi.org/10.1016/S0160-4120(02)00192-7

[43] Albercht. S.L. and Rasmussen, P.E. (1998) Soil Quality and Soil Organic Matter. Tektran. http://www.nal.usda.gov/ttic/tektran/data

[44] Pessarakli, M., Ed. (1999) Handbook of Plant and Crop Stress. 2nd Edition, CRC Press, Boca Raton, 1254 p. http://dx.doi.org/10.1201/9780824746728

[45] Mostajeran, A., Emtiazi, G. and Amouaghaei, R. (2005) The Effect of Azospirillum Brasilense and pH of Irrigation Water on Yield, Protein Content and Sedimentation Rate of Protein In Different Wheat Cultivars. Iranian Journal of Biology, 18, 248-260.

[46] Maas, E.V. and Grieve, C.M. (1989) Spike and Leaf Development of Sal-Stressed Wheat. Crop Science, 30, 13091313. http://dx.doi.org/10.2135/cropsci1990.0011183X003000060031x

[47] Francois, L.E., Grieve, C.M., Maas, E.V. and Lesch, S.M. (1993) Time of Salt Stress Affects Growth and Yield Components of Irrigated Wheat. Agronomy Journal, 86, 100-107. http://dx.doi.org/10.2134/agronj1994.00021962008600010019x 
[48] Francois, L.E., Mass, E.W., Donovan, T.J. and Youngs, V.L. (1986) Effect of Salinity on Grain Yield and Quality, Vegetative Growth, and Germination of Semi-Dwarf and Durum Wheat. Agronomy Journal, 78, 1053-1058. http://dx.doi.org/10.2134/agronj1986.00021962007800060023x

[49] Maas, E.V. and Poss, J.A. (1989) Salt Sensitivity of Wheat at Various Growth Stages. Irrigation Science, 10, $29-40$.

[50] Asadi, G., Ghorbani, R., Khorramdel, S. and Azizi, G. (2013) Effects of Wheat Straw and Nitrogen Fertilizer on Yield and Yield Components of Garlic (Allium sativum L.). Agricultural Science and Sustainable Production Journal, No. 4, 157-168.

[51] Mohamadi, M. (1998) Study the Correlation of Agronomic Traits with Grain Yield in Wheat (Triticum aestivum L.) at Dryland Conditions. Center of Agriculture Research Kohkolye and Boyerahmad, 11, 15-26.

[52] Kazemeini, S.A., Ghadiri, H., Karimian, N., Kamgar Haghighi, A.A. and Kheradnam, M. (2008) Interaction Effects of Nitrogen and Organic Matters on Growth and Yield of Dryland Wheat (Triticum aestivum L.). JWSS-Isfahan University of Technology, 12, 461-472.

\section{Submit or recommend next manuscript to SCIRP and we will provide best service for you:}

Accepting pre-submission inquiries through Email, Facebook, Linkedin, Twitter, etc A wide selection of journals (inclusive of 9 subjects, more than 200 journals)

Providing a 24-hour high-quality service

User-friendly online submission system

Fair and swift peer-review system

Efficient typesetting and proofreading procedure

Display of the result of downloads and visits, as well as the number of cited articles

Maximum dissemination of your research work

Submit your manuscript at: http://papersubmission.scirp.org/ 